\title{
ANATOMICAL AND CHEMICAL PROPERTIES OF JUVENILE Schizolobium amazonicum WOOD
}

Graziela Baptista Vidaurre ${ }^{2 *}$, Benedito Rocha Vital ${ }^{3}$, Jorge Luiz Colodette ${ }^{3}$, Angélica de Cássia Oliveira ${ }^{3}$, João Gabriel Missia da Silva ${ }^{4}$, Jordão Cabral Moulin ${ }^{5}$ and Denise Ransolin Soranso ${ }^{4}$

\footnotetext{
${ }^{1}$ Received on 27.07.2015 accepted for publication on 21.06.2017.

${ }^{2}$ Universidade Federal do Espírito Santo, Centro de Ciências Agrárias e Engenharia, Jerônim o Monteiro, ES-Brasil. E-mail: $<$ grazividaurre@gmail.com>.

${ }^{3}$ Universidade Federal de Viçosa, Departamento de Engenharia Florestal, Viçosa, MG-Brasil. E-mail:<bvital@ufv.br $>$, <colodett@ufv.br $>$ and < cassiacarneiro1@gmail.com>.

${ }^{4}$ Universidade Federal do Espírito Santo, Programa de Pós-Graduação em Ciências Florestais, Jerônim o Monteiro, ES-Brasil. E-mail: <j.gabrielmissia@hotmail.com> and < denise_soranso@hotmail.com>.

${ }^{5}$ Universidade Federal de Lavras, Doutorado em Tecnologia da Madeira, Lavras, MG-Brasil. E-mail: <jordao_cm@hotmail.com>.

*Corresponding author.
}

\begin{abstract}
The objective of this study was to determine the effects of tree age and of pith-bark and basetop positions on anatomical characteristics, and the effect of age on the chemical components of Schizolobium amazonicum (Paricá wood). The material was obtained from commercial plantations in the states of Maranhão and Pará with ages of 5, 7, 9 and 11 years. The first three logs $(2.7 \mathrm{~m}$ length each) were obtained from the trees of each age. Only the effect of age was analyzed for the chemical characterization of the wood. The dimensions of the fibers increased along the pith-bark direction, while wall thickness decreased and the length of the fibers increased with aging. The width of the fibers and the lume diameter increased in the base-top direction. Paricá wood presented low extractive and hemicellulose content, and high cellulose content. The anatomical characteristics were more affected by the factors under study than the chemical composition, evidencing that the chemical elements of the wood are more stable with aging in relation to the anatomical characteristics.
\end{abstract}

Keywords: Schizolobium amazonicum; Wood quality; Influence of age.

\section{PROPRIEDADES ANATÔMICAS E QUÍMICAS DA MADEIRA JUVENIL DE PARICA}

\begin{abstract}
RESUMO - O objetivo deste trabalho foi determinar os efeitos da idade das árvores e das posições medulacasca e base-topo nas características anatômicas e o efeito da idade nos componentes químicos da madeira de Schizolobium amazonicum (paricá). O material foi obtido de plantios comerciais nos estados do Maranhão e Pará, com idades de 5, 7, 9 e 11 anos. Das árvores de cada idade foram obtidas as três primeiras toras (de 2,7 m de comprimento cada). Para a caracterização química da madeira analisou-se apenas o efeito da idade. As dimensões das fibras aumentaram no sentido medula-casca, enquanto a espessura da parede reduziu e o comprimento das fibras aumentou juntamente com a idade. A largura das fibras e o diâmetro do lume aumentaram no sentido base-topo. A madeira de paricá apresentou baixo teor de extrativos e de hemiceluloses, e alto teor de celulose. As características anatômicas foram mais afetadas pelos fatores em estudo do que a composição química, evidenciando que os elementos químicos da madeira são mais estáveis com a idade em relação aos caracteres anatômicos.
\end{abstract}

Palavras-Chave: Schizolobium amazonicum, Qualidade da madeira, Influência da idade. 


\section{INTRODUCTION}

Brazilian flora is extremely rich in biodiversity and only a small number of species have been studied in terms of characterization and for defining rational uses. The national and international timber market has a small number of commercially accepted species, and this restriction is due to the incipient knowledge of the characteristics of other non-traditional wood-based essences. Moreover, the absence of studies on quality and the potential of wood promotes a lack of information, even for genera that already have economic importance, leading to a decline in usage possibilities and increasing substitution by other materials (Baldin et al., 2016; Klein et al., 2016).

The native species Schizolobium amazonicum (Huber) ex. Ducke, Caesalpinaceae family, popularly known (in Brazil) as Paricá or pinho-cuiabano, has been cultivated in the northern region of Brazil for producing laminated veneers for manufacturing plywood; and also in forest replenishment as an option for land use in order to recover areas altered by agriculture and livestock (Modes, 2016). This species is notable for its rapid growth (cutting cycles around 6-7 years of age), a straight stem and a low incidence of nodes, which increases the yield of good quality sheets. Due to its low density, the wood does not require cooking for lamination, which reduces the final production costs. These advantages have motivated an increase in commercial plantations of this species, reaching an area of 90,047 ha in 2015 (IBÁ, 2016).

In tropical countries such as Brazil, the cutting cycles are short due to favorable conditions for growth and timber production, making forestry enterprise more profitable. Much research has already been developed with fast growing species of the genus Eucalyptus and Pinus to determine the effects of age and trunk positions on wood properties (Valente et al., 2013). However, this research is still scarce for the native species of the Amazon and other regions.

Anatomical information on the dimensions of Paricá wood fibers and vessels will support studies for their use in new products, such as cellulosic pulp and paper (Silva et al., 2013); LVL - Laminated Veneer Lumber (Iwakiri et al., 2010; Melo and Del Menezzi, 2015), MDF - Medium Density Fiberboard (Ribeiro, 2015) and OSB - Oriented Strand Board (Ferro et al., 2015); as well as panels and glue laminated timber-GLULAM

Revista Árvore. 2018;42(3):e420301
(Terezo and Szücs, 2010; Almeida et al., 2011). In addition, the sheet bonding process for producing plywood, application of adhesives and preservatives, and the wood drying and finishing can be improved when the variability and proportion of vessel elements in Paricá wood are known in relation to age and position in the trunk.

In order to determine the potential of new products, it is necessary to evaluate the different chemical components of the wood, since its constituents are related to its properties and also to its products. For example, wood with high uronic acid content consumes more amount of alkali during woodchip cooking for the production of cellulosic pulp (Gomide et al., 2005).

The chemical and anatomical composition of wood varies between species and within the tree itself; and this occurs due to environmental, genetic and age factors (Trugilho et al., 1996). According to the authors, variations in the chemical and anatomical element values occur throughout the course of years until transition to adult wood, when they remain more or less constant.

Variability of these components within the tree among pith-bark and base-top directions must be considered when analyzing the chemical and anatomical characterization of wood. With this sampling, it is possible to understand the heterogeneity of these wood components in the tree, and to identify its best technological use (Valente et al., 2013).

The information contained in this study will help support future selection, genetic improvement and forestry management of this Amazonian species, contributing to improving the quality and increased use of this wood. Our objective was to determine the effects of tree age as well as pith-bark and base-top positions of the commercial trunk on the characteristics of fibers and vessels, and the effects of age on the chemical components of Paricá wood.

\section{MATERIALAND METHODS}

The material used in this work was collected at commercial plantations of companies located in Pará, Brazil. Four different ages were evaluated: the fiveyear plantation was located in the municipality of Itinga do Maranhão - MA (Latitude: $04^{\circ} 40^{\prime}$ and longitude: $47^{\circ} 36^{\prime}$ ), while seven-year trees were collected in the region of Dom Eliseu - PA(Latitude: $04^{\circ} 12^{\prime}$ ' and longitude: 
$\left.47^{\circ} 27^{\prime}\right)$, and nine and eleven-year plantations were both located in the municipality of Paragominas - PA (Latitude: $02^{\circ} 48^{\prime}$ and longitude: $47^{\circ} 25^{\prime}$ '). All four plantations were spaced $4 \times 4 \mathrm{~m}$.

The climate of the localities is humid mesothermic, with an average annual temperature around $25^{\circ} \mathrm{C}$ and mean daily minimums around $20^{\circ} \mathrm{C}$, with average rainfall between 2,250 and 2,500 $\mathrm{mm}$. The rain periods are not distributed equally throughout the year, with the highest concentration between January and June (about 80\%). The relative humidity of the air was around $85 \%$.

Four trees were randomly selected (considered repetitions) for each age studied. After being harvested, the trees were sectioned into $2.7 \mathrm{~m}$ logs from the base, and the first three logs were analyzed in this study. Cross-sectional disks were removed from the base of each $\log$, totaling three disks per tree and 12 per age to be used in the anatomical and chemical analyses of the wood.

The anatomical characterization of the wood was carried out from pith-to-bark and from base-to-top of the commercial stem. Three $1.0 \times 1.0 \times 1.0 \mathrm{~cm}$ samples were taken from each disc at equidistant points, corresponding to 0,50 and $100 \%$ of the pith-bark section, thereby totaling 144 samples for maceration and crosssections for measuring the tangential diameter and frequency of the vessels.

Macerates for characterizing the fibers were prepared using glacial acetic acid solution and hydrogen peroxide (1:1) (Dadswell, 1972). The mixture was oven-dried at $60^{\circ} \mathrm{C}$ for a period of 34 hours. The sheets were assembled and the individual fiber dimensions were measured. Cell wall thickness was determined by half the difference between the fiber width and the lume diameter. The indices used for the fiber and paper quality analyses were then calculated from these parameters. The Runkel index determination was obtained by the ratio between the wall thickness and the fiber lume diameter, and the felting index through the length and width ratio of the fiber, with all dimensions being in the same measurement units. The coefficient of flexibility was determined by the lume diameter and the fiber width ratio, and the wall fraction by the wall thickness and total fiber width ratio.

With the aid of sliding microtome, anatomical sections of the cross-section ( $18 \mu \mathrm{m}$ thickness) were made to measure the tangential diameter and frequency of the vessels. The anatomical sections were clarified with $60 \%$ sodium hypochlorite solution and then stained with $1 \%$ safranin; permanent sheets were subsequently assembled.

An optical microscope with an imaging acquisition system coupled with a camera was used, allowing visualization of the fibers and vessels directly in the monitor and for later image capture with the aid of AxioVision software.

Only the effect of age was analyzed for the chemical characterization of Schizolobium amazonicum wood, without considering the pith-bark and base-top variability regarding trunk positioning. Two opposing wedges were removed from each wooden disk, each corresponding approximately to $1 / 8$ of the disc section, and which were later reduced to sawdust using a Wiley laboratory mill (TAPPI, 1996). The sawdust was then retained in 40 and 60 mesh sieves for chemical analyzes (SCAN, 1989).

Wood free of extractives was initially obtained, and then the other chemical analyzes were carried out from the remaining extract, except for the analysis of the ash content and elemental wood composition. Determination of the elemental chemical composition was carried out with the sawdust retained in the 80 mesh sieve via dry combustion in a Perkin Elmer elemental analyzer. Syringyl/guaiacyl lignin (S/G) was determined by HPLC after sawdust oxidation with nitrobenzene, and carbohydrates were determined by gas chromatography after acid hydrolysis.

The norms and methodologies used for chemical characterization were: ashes (TAPPI, 2012), extractives in acetone (Solar et al., 1987), extractives in cyclohexane/ ethanol (TAPPI, 1998/1999), extractives in hot water (TAPPI, 1994), Klason lignin (TAPPI, 2011), acid-soluble lignin (TAPPI, 1991), total uronic acids (Scott, 1979), syringyl/guaiacyl lignin (S/G) (Lin and Dence, 1992) and carbohydrates (TAPPI, 2009).

For anatomical characterization, the experiment was performed according to a complete factorial analysis with three positions in the pith-bark direction $(0,50$ and $100 \%)$, three base-top positions $(\operatorname{logs} 1,2$ and 3 ) and four ages $(5,7,9$ and 11 years), totaling 36 treatments with four replicates. For chemical characterization, the experiment followed a completely randomized design with four ages and four replicates. The results were interpreted using analysis of variance, 
and the Tukey test was applied for averages at 5\% significance when there was a difference established between them.

The Pearson correlation matrix at 5\% significance was applied to evaluate the possible correlations between the anatomical and chemical properties of the wood and the variables, age, and sampling positions.

\section{RESULTS}

\subsection{Characterization of fibers and vessels}

Overall, the fiber and vessel dimensions showed variations in relation to age and pith-bark and baseto-top direction of the trees. However, no significant interaction between these factors were found.

Variations in the pith-bark direction were more expressive than those observed at different ages and along the trunk. All anatomical parameters of the fibers and vessels were correlated with the pith-bark position. In general, the trees' age was the variable that least influenced the anatomical elements of the wood.

Regarding the fiber dimensions, only the width and lume diameter at the base-top positions of the trunk were significant. Both the frequency and the tangential diameter of the vessels were significantly affected by the positions along the trunk.

The following trends for Paricá wood fibers were observed (Figure 1):

a) The fiber length was proportional to the increase in age, increasing in the pith-bark direction (in the positions of 0 to $100 \%$ of the radius), however, without any significant changes along the height of the trunk.

b) The width and lume diameter of the fibers were greatest in nine-year-old wood.

c) Wall thickness decreased with increasing age. The increase in wall thickness was observed in the pith-bark direction, however no variations in the basetop direction were noticed.

d) Length was the fiber variable that presented the most variation both in terms of age and in the pithbark position.

e) Pith-bark variation was more pronounced than what was seen in the base-top direction, while the age variation was less relevant than that occurring inside of the trees.
The age and base-to-top position significantly affected the four anatomical indices used to evaluate the fiber quality for cellulosic pulp production (Table 1). Regarding the pith-bark positions, only the felting index varied significantly. However, no significant interactions between the factors studied were observed for fiber quality indices.

Despite the significant effect of age, no clear variation regarding the decrease or increase in coefficient values was found, similar to what was observed for the pith-bark and base-top positions of the trunk regarding the felting index.

We found that the age of the trees did not alter the frequency of the vessels, however the tangential diameter was significantly influenced by the passing of years (Figure 2). The following results for vessel characteristics can be observed:

a) A decrease in vessel frequency was observed for the two forms of trunk sampling evaluated. In general, the number of vessels per $\mathrm{mm}^{2}$ presented a $35 \%$ reduction in the pith-bark direction, and $16 \%$ along the height of the trees.

b) Contrary to frequency, the tangential diameter increased for all factors studied, meaning according to the age and the sampling positions.

c) In general, vessel diameter increased 30 and $12 \%$ in the pith-bark and base-top directions of the trees, respectively. The values of vessel tangential diameter at 11 years were $15 \%$ greater compared to at the age of 5 years.

\subsection{Chemical composition}

The effect of age on the chemical composition of Paricá wood is shown in Table 2. The elemental composition values among the ages were not compared since there were no repetitions during the analyzes.

The extractives content soluble in acetone and hot water were not affected by aging. Age only influenced solubility in ethanol. The wood at younger ages was more soluble in ethanol, unlike wood at a more advanced age which presented greater solubility in hot water at nine years.

The trees' age also influenced uronic acid content in the wood, as the youngest age presented the highest average value.

Revista Árvore. 2018;42(3):e420301 

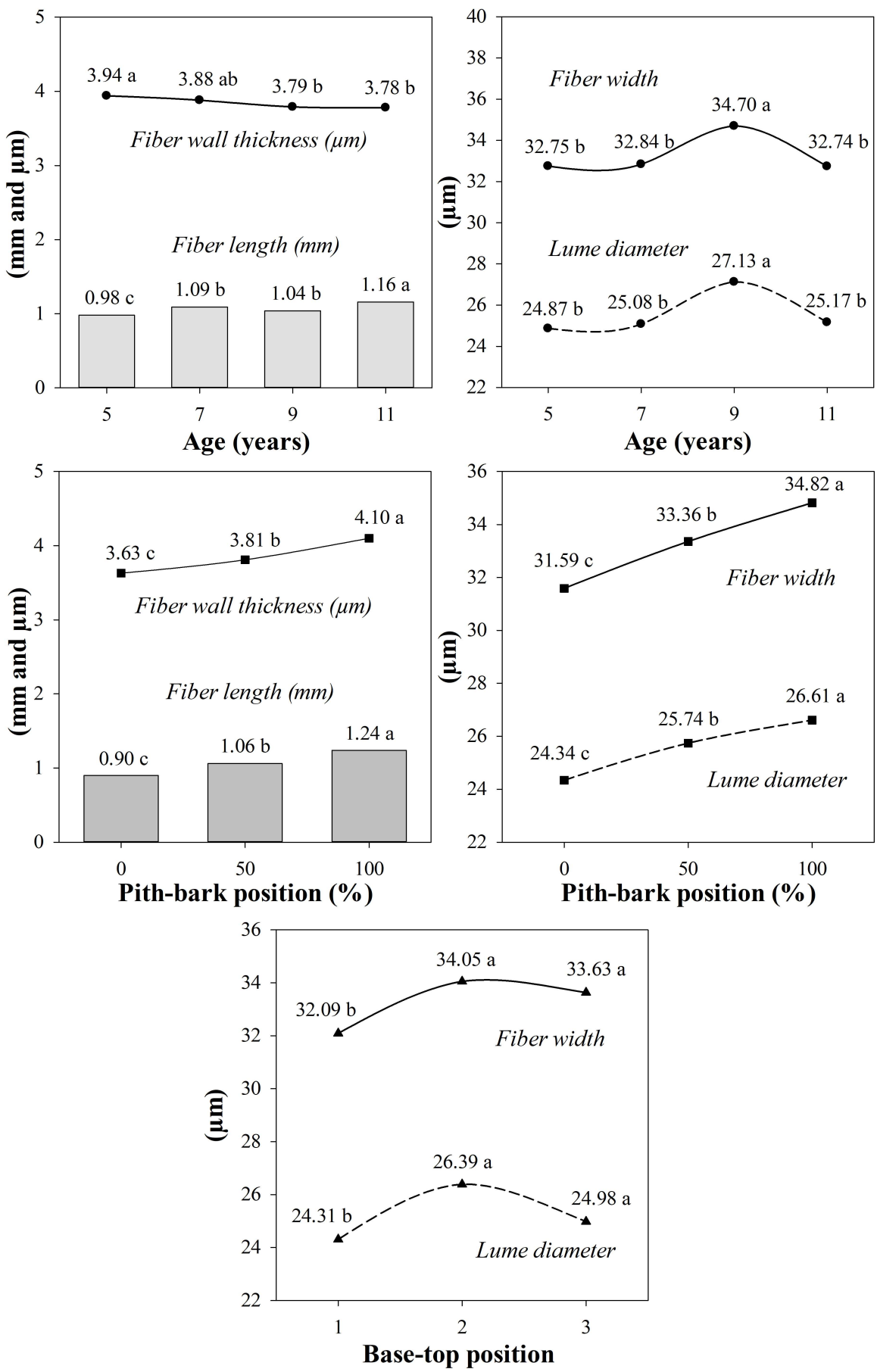

Figure 1 - Effect of age, pith-bark and base-top positions on length, wall thickness, lume width and diameter of the Paricá wood fibers. Means followed by the same letter do not differ by Tukey test at $5 \%$ of significance

Figura 1 - Efeito da idade e posições medula-casca e base-topo no comprimento, espessura da parede, largura e diâmetro do lume das fibras da madeira de paricá. Médias seguidas pela mesma letra não diferem entre si pelo teste de Tukey a 5\% de significância. 
Table 1 - Indicative coefficients of Paricá fiber quality for the production of cellulosic pulp according to age, base-top and pith-bark positions.

Tabela 1 - Coeficientes indicativos de qualidade das fibras de paricá para produção de polpa celulósica, em função da idade e posições base-topo e medula-casca.

\begin{tabular}{|c|c|c|c|c|c|c|c|c|c|c|}
\hline \multirow{2}{*}{ Index } & \multicolumn{4}{|c|}{ Age (years) } & \multicolumn{3}{|c|}{ Base-top position (Log) } & \multicolumn{3}{|c|}{ Pith-bark position (\%) } \\
\hline & 5 & 7 & 9 & 11 & 1 & 2 & 3 & 0 & 50 & 100 \\
\hline CFlex & $0.75 \mathrm{~b}^{*}$ & $0.76 \mathrm{~b}$ & $0.78 \mathrm{a}$ & $0.76 \mathrm{~b}$ & $0.75 \mathrm{~b}$ & $0.77 \mathrm{a}$ & $0.77 \mathrm{a}$ & $0.76 \mathrm{a}$ & $0.76 \mathrm{a}$ & $0.77 \mathrm{a}$ \\
\hline WF & $0.12 \mathrm{a}$ & $0.11 \mathrm{a}$ & $0.10 \mathrm{~b}$ & $0.11 \mathrm{a}$ & $0.12 \mathrm{a}$ & $0.11 \mathrm{~b}$ & $0.11 \mathrm{~b}$ & $0.11 \mathrm{a}$ & $0.11 \mathrm{a}$ & $0.11 \mathrm{a}$ \\
\hline FI & $20.00 \mathrm{c}$ & $31.00 \mathrm{~b}$ & $30.00 \mathrm{c}$ & $33.00 \mathrm{a}$ & $33.00 \mathrm{a}$ & $31.00 \mathrm{~b}$ & $31.00 \mathrm{~b}$ & $35.00 \mathrm{a}$ & $28.00 \mathrm{c}$ & $31.00 \mathrm{~b}$ \\
\hline RI & $0.24 \mathrm{a}$ & $0.23 \mathrm{a}$ & $0.21 \mathrm{~b}$ & $0.23 \mathrm{a}$ & $0.24 \mathrm{a}$ & $0.22 \mathrm{~b}$ & $0.22 \mathrm{~b}$ & $0.23 \mathrm{a}$ & $0.23 \mathrm{a}$ & $0.22 \mathrm{a}$ \\
\hline
\end{tabular}

Cflex: coefficient of flexibility; WF: wall fraction; FI: felting index; and RI: Runkel index. ${ }^{*}$ Means followed by the same letter in the same line and for the same factor do not differ among themselves by the Tukey test at $5 \%$ significance.
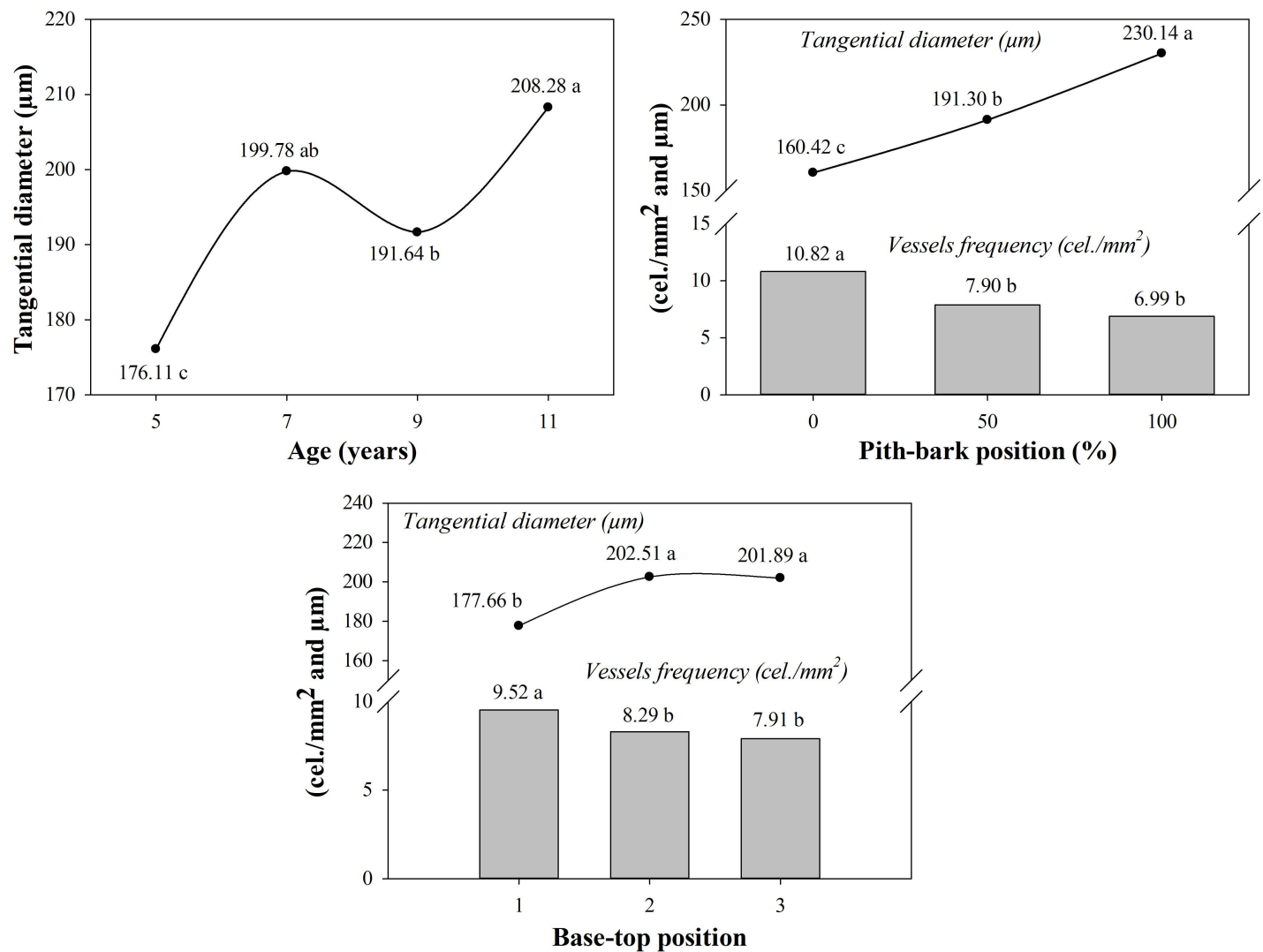

Figure 2 - Effect of pith-bark and base-top position and of tree age in the frequency and tangential diameter of Paricá wood vessels. Means followed by the same letter do not differ from each other by the Tukey test at $5 \%$ significance.

Figura 2 - Efeito da posição medula-casca e base-topo e da idade das árvores na frequência e diâmetro tangencial dos vasos da madeira de paricá. Médias seguidas pela mesma letra não diferem entre si, pelo teste de Tukey a 5\% de significância.

Average raminana content decreased and average glycan content increased with increasing age. Average xylan and 4-O-methyl-glucuronic acid contents did not show a definite variation. Cellulose content increased with age, while hemicellulose content decreased (Table 2).
The ash content of the wood was higher at five years, however it did not definitively increase with advancing age.

Insoluble and soluble lignin contents did not differ between ages, and age influenced the syringyl/guaiacyl ratio (S/G), but without demonstrating a defined behavior.

Revista Árvore. 2018;42(3):e420301 
Table 2 - Chemical composition of Paricá wood at different ages.

Tabela 2 - Composição química da madeira de paricá em diferentes idades.

\begin{tabular}{|c|c|c|c|c|}
\hline \multirow[t]{2}{*}{ Chemical Component (\%) } & \multicolumn{4}{|c|}{ Age (years) } \\
\hline & 5 & 7 & 9 & 11 \\
\hline \multicolumn{5}{|l|}{ Elemental Composition: } \\
\hline Carbon & 45.39 & 45.33 & 45.32 & 45.65 \\
\hline Hydrogen & 6.78 & 6.20 & 6.26 & 6.60 \\
\hline Nitrogen & 0.12 & 0.35 & 0.14 & 0.24 \\
\hline Oxygen & 47.71 & 48.12 & 48.28 & 47.51 \\
\hline Extractives in Acetone & 1.59 & 1.78 & 1.60 & 1.72 \\
\hline Extractives in Ethanol & $2.19 \mathrm{~b}$ & $2.86 \mathrm{a}$ & $2.10 \mathrm{~b}$ & $2.14 \mathrm{~b}$ \\
\hline Solubility in hot water & 2.15 & 2.11 & 2.49 & 1.93 \\
\hline Uronic Acids & $1.10 \mathrm{ab}$ & $0.95 \mathrm{~b}$ & $1.00 \mathrm{ab}$ & $0.95 \mathrm{~b}$ \\
\hline 4-O-methyl-glucuronic acid & $0.91 \mathrm{ab}$ & $0.89 \mathrm{~b}$ & $1.05 \mathrm{a}$ & $0.94 \mathrm{ab}$ \\
\hline Glycans & $50.34 \mathrm{~b}$ & $50.61 \mathrm{~b}$ & $51.49 \mathrm{a}$ & $51.80 \mathrm{a}$ \\
\hline Xylan & $11.17 \mathrm{a}$ & $10.59 \mathrm{~b}$ & $11.20 \mathrm{a}$ & $10.61 \mathrm{~b}$ \\
\hline Galactans & 0.48 & 0.43 & 0.44 & 0.41 \\
\hline Arabinans & 0.24 & 0.22 & 0.24 & 0.23 \\
\hline Mannans & $1.05 \mathrm{c}$ & $1.18 \mathrm{a}$ & $0.87 \mathrm{~d}$ & $1.07 \mathrm{~b}$ \\
\hline Raminana & $0.27 \mathrm{a}$ & $0.26 \mathrm{a}$ & $0.25 \mathrm{~b}$ & $0.24 \mathrm{~b}$ \\
\hline Cellulose $^{(\mathrm{b})}$ & $49.32 \mathrm{~b}$ & $49.45 \mathrm{~b}$ & $50.65 \mathrm{a}$ & $50.76 \mathrm{a}$ \\
\hline Hemicellulose $^{(\mathrm{c})}$ & $15.36 \mathrm{a}$ & $14.81 \mathrm{~b}$ & $14.87 \mathrm{~b}$ & $14.58 \mathrm{~b}$ \\
\hline Ashes & $0.82 \mathrm{a}$ & $0.57 \mathrm{c}$ & $0.67 \mathrm{~b}$ & $0.60 \mathrm{c}$ \\
\hline Insoluble Klason lignin & 27.63 & 27.80 & 27.85 & 27.25 \\
\hline Soluble lignin & 2.08 & 1.73 & 1.83 & 1.98 \\
\hline Total Lignin & 29.71 & 29.53 & 29.68 & 29.23 \\
\hline Syringyl/Guaiacyl Lignin ratio & $1.03 \mathrm{a}$ & $1.06 \mathrm{ab}$ & $1.13 \mathrm{a}$ & $1.06 \mathrm{ab}$ \\
\hline
\end{tabular}

\subsection{Pearson's Correlation}

Correlations that were significant for the age and sampling position factors with the anatomical properties and chemical components are listed in Table 3.

\section{DISCUSSION}

\subsection{Characterization of fibers and vessels}

The variation in size and shape of cellular elements is less consistent in the base-top direction when compared to the pith-bark direction of the trunk (Wilkes, 1988). In this context, little consistency in the variation of anatomical elements in the base-top direction of fast-growing tropical zone tree species was found by Urbinati et al. (2003), Rocha et al. (2004), Quilhó et al. (2006) and Gonçalez et al. (2014).

Fiber length and diameter of Paricá wood vessels increased with the tree age. Wall thickness decreased in older trees, contrary to what is reported in the literature for other species (Silva et al., 2007; Sette Jr. et al., 2012).

Table 3 - Pearson's Correlations between ages and trunk positions with fibers, vessels and chemical components.

Tabela 3 - Correlações de Pearson entre a idade e posições no tronco com as fibras, vasos e componentes químicos.

\begin{tabular}{|c|c|c|c|c|c|c|c|c|c|c|}
\hline \multirow{3}{*}{ Variáveis } & \multicolumn{10}{|c|}{ Pearson's Correlation Coefficients } \\
\hline & \multicolumn{4}{|c|}{ Fibers } & \multicolumn{2}{|c|}{ Vessels } & \multicolumn{4}{|c|}{ Chemical components } \\
\hline & $\mathrm{FL}^{*}$ & FW & DL & WT & $\mathrm{TD}$ & VF & IL & GLUCO & GALA & MANN \\
\hline Age & 0.31 & $\mathrm{~ns}$ & $\mathrm{~ns}$ & -0.22 & 0.24 & $\mathrm{~ns}$ & 0.78 & 0.96 & -0.72 & -0.96 \\
\hline $\begin{array}{l}\text { Base-top } \\
\text { position }\end{array}$ & ns & 0.24 & 0.28 & ns & 0.24 & -0.18 & ns & ns & $\mathrm{ns}$ & $\mathrm{ns}$ \\
\hline $\begin{array}{l}\text { Pith-bark } \\
\text { position }\end{array}$ & 0.43 & -0.23 & $\mathrm{~ns}$ & -0.40 & 0.70 & -0.56 & ns & ns & $\mathrm{ns}$ & $\mathrm{ns}$ \\
\hline
\end{tabular}

FL: fiber length, FW: fiber width, DL: lume diameter, and WT: fiber wall thickness; TD: tangential diameter, and VF: vessel frequency; IL: insoluble lignin; GLUCO: glucose; GALA: galactose; and MANN: mannose. 
The other parameters did not show the same consistency. The average fiber length values are in line with those normally found in juvenile eucalyptus wood, which is a widely used species for various purposes in Brazil (Quilhó et al., 2006; Silva et al., 2007), and those described by Sahrim et al. (1993) for juvenile Acacia mangium wood planted in Malaysia, and also slightly smaller when compared to Gmelina arborea planted in Costa Rica (Roque and Tomazelo Filho, 2009) and Tectona grandis in India (Bhat et al., 2001).

Paricá wood has average fiber width and intermediate lume diameter values when compared to Eucalyptus and Pinus wood planted in Brazil, and similar values to the species Schizolobium parayba and Ceiba pentandra, which are commercially-used Brazilian species having similar basic density values (Manieri and Chimelo, 1989).

For all ages, the coefficient of flexibility was higher than that normally found for eucalyptus wood and the wall fraction was lower (Ferreira et al., 2006; Florsheim et al., 2009). Ferreira et al. (2006) reported that lower wall fraction and higher coefficient of flexibility values may present greater flattening during paper formation, which is desirable for producing printing and writing paper, and undesirable for producing tissue paper. The age of five years presented the best relationship between the variables.

Values above 0.40 for the wall fraction do not produce good quality cellulose as the fibers are extremely rigid and poorly flexible (Foelkel and Barrichelo, 1975). For all situations analyzed for Paricá wood, the wall fraction was lower than the value suggested by the authors, and the Runkel index for all factors is considered to be excellent for paper (lower than 0.25). Based on these indices, this means Paricá wood has suitable characteristics for paper production.

\subsection{Chemical composition}

The carbon content of Paricá wood was lower than that found for eucalyptus planted in Brazil, and did not present a reduction with increasing age of the tree, as observed by Gomide and Colodette (2007) for eucalyptus wood intended for cellulosic pulp production. A factor of 0.5 is used in forestry projects for evaluating the carbon stock estimation recommended by the IPCC (2003), which considers that the carbon percentage in wood is $50 \%$ on average. Thus, the use of this scale in carbon credit projects with this species would be overestimating the presence of this element in the wood.

Acetone and the toluene:ethanol mixture were the most efficient solvents for determining total extractive content. No variation with aging of the tree was found regarding the quantities of substances such as (natural) gums, tannins, sugars, dyes and starch (Oliveira et al., 2005) for solubility in hot water extracts from the Paricá wood studied.

The low presence of extractives can be explained by the low age of the evaluated material, since even the 11-year-old trees are considered young and still have heartwood impregnated by these materials. The heartwood formation process is characterized by an increase of extractive content in the wood (Silva and Trugilho, 2003).

In principle, the low extractive content compared to other tropical species reduces the probability of interference in the adhesive polymerization process in the wood veneer/sheet bonding (Lima et al., 2007). In this study, the extractives present in Paricá wood were not identified, only their total percentage. However, it is possible that some components present in extractives, even at small concentrations, may interfere with the bonding process of the veneers/sheets. For example, the $\mathrm{pH}$ of some extractives inhibits the chemical hardening reactions of the adhesive, interfering in the development of adequate strength and cohesion during the bonding process (Marra, 1992). Therefore, qualitative studies of certain extractable components are important for greater advance in the quality of the wood of this tropical species.

Glycan content increased with age, and consequently the cellulose content in wood also increased with age. In general, hemicellulose content decreased with age, which can be explained by the higher deposition percentage of cellulose chains in relation to the hemicellulose chains. Similar results were observed by Morais et al. (2017) for wood clones of Eucalyptus grandis and the hybrid of Eucalyptus grandis $\mathrm{x}$ Eucalyptus urophylla planted in Ipatinga - MG.

The hemicellulose content in the Paricá wood was lower compared to the eucalyptus wood (Mokfienski et al., 2008). This is a positive characteristic, as the yield in the pulping process is positively correlated with the glycan content in the wood (Ferreira et al., 2006).

Revista Árvore. 2018;42(3):e420301

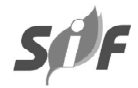


Mainly with respect to cellulose content, the carbohydrate fraction of Paricá wood is similar to some eucalyptus clones used in the pulp and paper industry (Mokfienski et al., 2008). In this theme, Morais et al. (2017) concluded that a comprehensive analysis of carbohydrates and groups that make up the fibrous material of wood can be more useful when treated as cellulose and hemicellulose only, since the final product is basically composed of these elements, and they provide reliability for describing the raw material that arrives at the factory.

Hardwoods can present three different types of uronic acids: 4-O-methyl-glucuronic acid, D-galacturonic acid and D-glucuronic acid (Willför et al., 2009). However, according to the values obtained for the studied wood, practically all uronic acids found were of a single type, namely 4-O-methyl-glucuronic acid.

According to the pattern found in the hemicellulose, and as they are lateral branches of hemicellulosic chains, the uronic acids content also decreased with the increase of age. An interesting characteristic is the low content of uronic acids in relation to eucalyptus wood, which is an advantage for producing cellulosic pulp due to the lower consumption of reagents during (wood) cooking (Gomide et al., 2005).

Several studies have reported that lignin content tends to decrease with age (Bendtsen, 1978; Sjöström, 1981; Zobel and van Buijtenen, 1989; Trugilho et al., 1996; Yeh et al., 2006; Guler et al., 2007). This reduction of lignin with age was not observed for Paricá wood up to 11 years. A similar situation was observed by Soares et al. (2015) in the wood of young trees (3, 5 and 7 years old) of the E. grandis $x$ E. urophylla hybrid. In contrast, Neves et al. (2013) found an increase of $12.1 \%$ in the lignin content of Eucalyptus spp. clones in only one year of tree growth (4 years and 7 months, and 5 years and 7 months). Thus, the variability of lignin content with advancing age may be a reflection of the effect of factors other than age, such as site, management and genetic potential.

The total lignin content in Paricá wood is high in relation to other temperate hardwoods such as Fagus sylvatica (Antonovic et al., 2010), Betula pendula (Borrega et al., 2011) and Populus sp. (Sannigrahi et al., 2010), resembling the content present in coniferous wood. However, hardwoods growing in tropical climates tend to normally produce high concentrations of lignin, as is in the case of eucalyptus planted in Brazil, which has average lignin content between 25 and $30 \%$ (Gomide and Colodette, 2007).

The average value for soluble lignin present in Paricá wood for the four ages evaluated was $1.89 \%$; a value below the average (3.5-5.0\%) found for Eucalyptus sp. wood planted in Brazil for production of cellulosic pulp (Mokfienski et al., 2008).

The $\mathrm{S} / \mathrm{G}$ ratio showed that the frequency of the syringil structures was slightly higher than guaiacyl content in Paricá wood. Higher ratios are desirable for pulping since syringyl structures can be more easily degraded by cooking reagents, thus requiring fewer reagents to achieve the same final Kappa number, which results in lower yield losses (Colodette, 2006). For Paricá wood use in the production of cellulosic pulp, initial studies on the influence of the $\mathrm{S} / \mathrm{G}$ ratio on the pulping are recommended, as well as development of breeding programs with the aim to reduce total lignin and extractive content and increase the soluble lignin content.

The ash content is relatively high, being negative for most chemical wood conversion processes. The great amount of minerals in Paricá wood is a reflection of its rapid growth associated with the characteristics of the growth site and logging at a young age.

\subsection{Correlation}

The vessel parameters showed a greater correlation with pith-bark positions in relation to the other evaluated anatomical characteristics. Despite few chemical components being related to age, the highest correlation coefficients of this study were observed.

\section{CONCLUSION}

Anatomical characteristics were more affected by age than the chemical composition, demonstrating that the chemical elements of the wood are more stable with aging in comparison to the anatomical traits.

Variations in fiber dimensions occurred as a function of aging, especially regarding the pith-bark position. The chemical composition of wood also varied with aging.

In principle, a factor of 0.45 for Paricá wood in carbon credit projects is recommended, in which the age of the trees is between five and 11 years. 
Among the analyzed lignin, only the $\mathrm{S} / \mathrm{G}$ ratio was influenced by tree age. Paricá wood presented low extractive content and carbohydrate content similar to that found for eucalyptus wood.

\section{ACKNOWLEDGEMENTS}

To the Laboratory of Wood Chemistry of the University of Hamburg (Germany) in the Dr. Othar Kordosachia and Prof. Dr. Rudolph Patt for carbohydrate and lignin analysis. To the Mr. Luciano Zaneti.

\section{REFERENCES}

Almeida DH, Scaliante RM, Macedo LB, Macêdo AN, Calil Junior C. Madeira laminada colada (MLC) da espécie Paricá. Madeira: Arquitetura e Engenharia. 2011;12(30):71-82.

Antonovic A, Jambrekovic V, Franjic J, Spanic N, Pervan S, Istvanic J, et al. Influence of sampling location on content and chemical composition of the beech native lignin (Fagus sylvatica L.). Periodicum Biologorum. 2010;112(3):327-32.

Baldin T, Siegloch AM, Marchiori JNC. Compared anatomy of species of Calycophyllum DC. (Rubiaceae). Revista Árvore. 2016;40(4):759-68.

Bendtsen B. Properties of wood from improved and intensively managed trees. Forest Products Journal. 1978;28(10):61-72.

Bhat KM, Priya PB, Rugmini P. Characterization of juvenile wood in teak. Wood Science and Technology. 2001;34(6):517-32.

Borrega M, Nieminen K, Sixta H. Effects of hot water extraction in a bath reactor on the delignification of birch wood. BioResources. 2011;6(2):1890-903.

Colodette J. The importance of increasing Eucalyptus Syringyl/ Guaiacyl ratio (S/G) on overall pulp mill economic. Campinas: ArboGen; 2006.

Dadswell HE. The anatomy of eucalypt wood. Melbourne: CSIRO/ Forest Products Laboratory; 1972.

Ferreira CR, Fantini Junior M, Colodette JL, Gomide JL, Carvalho AMML. Avaliação tecnológica de clones de eucalipto: parte 1- qualidade da madeira para a produção de celulose Kraft. Scientia Forestalis. 2006(70):161-70.
Ferro FS, Icimoto FH, Souza AM, Almeida DH, Christoforo AL, Lahr FAR. Produção de painéis de partículas orientadas (OSB) com

Schizolobium amazonicum e resina poliuretana à base de óleo de mamona. Scientia Forestalis. 2015;43(106):313-20.

Florsheim SMB, Couto HTZ, Lima IL, Longui EL. Variação nas dimensões dos elementos anatômicos da madeira de Eucalyptus dunnii aos sete anos de idade. Revista do Instituto Florestal. 2009;21(1):79-91.

Foelkel CE, Barrichelo LEG. Tecnologia de celulose e papel. Piracicaba: USP; 1975.

Gomide JL, Colodette JL. Qualidade da madeira. In: Borén A. Biotecnologia florestal. Viçosa: UFV; 2007. p.25-54.

Gomide JL, Colodette JL, Oliveira RC, Silva CM. Caracterização tecnológica, para produção de celulose, da nova geração de clones de Eucalyptus do Brasil. Revista Árvore. 2005;29(1):129-37.

Gonçalez JC, Santos GL, Silva Junior FG, Martins IS, Costa JA. Relações entre dimensões de fibras e de densidade da madeira ao longo do tronco de Eucalyptus urograndis. Scientia Forestalis. 2014;42(101):81-9.

Guler C, Copu Y, Akgul M, Buyuksari U. Some chemical, physical and mechanical proprieties of juvenile wood from Black pine (Pinus nigra Arnold) plantations. Journal of Applied Sciences. 2007;7(5):755-8.

Indústria Brasileira de Árvores - IBÁ. Relatório IBÁ 2016. Brasília: IBÁ; 2016.

Intergovernamental Panel on Climate Change IPCC. Good practice guidance for land use, land-use change and forest. 2003. [accessed em: $10 \mathrm{Feb}$. 2010]. Disponível em: http://www. ipccnggip.iges.org.jp/public/gpglulucf/ gpglulucf_contents.html.

Iwakiri S, Matos JLM, Pinto JA, Viana LC, Souza $\mathrm{MM}$, Trianoski R, et al. Produção de painéis laminados unidirecionais - LVL com lâminas de Schizolobium amazonicum, Eucalyptus saligna e Pinus taeda. Cerne. 2010;16(4):557-63.

Revista Árvore. 2018;42(3):e420301 
Klein A, Bockhorn O, Mayer K, Grabner M. Central European wood species: characterization using old knowledge. Journal of Wood Science.

2016;62(2):194-202.

Lima CKP, Mori FA, Mendes LM, Carneiro ACO. Características anatômicas e química da madeira de clones de Eucalyptus e sua influência na colagem. Cerne. 2007;13(2):123-9.

Lin SY, Dence CW. Methods in lignin chemistry. Berlin: Springer-Verlag; 1992. 578p.

Manieri C, Chimelo JP. Fichas características das madeiras brasileiras. 2a ${ }^{a}$ ed. São Paulo: IPT; 1989.

Marra AA. Technology of wood bonding: principles and practice. New York: Van Nostrand Reinhold; 1992.

Melo RR, Del Menezzi CHS. Influence of adhesive type on the properties of LVL made from Paricá (Schizolobium amazonicum Huber ex. Ducke) plantation trees. Drvna Industrija. 2015;66(3):20512.

Modes KS. Caracterização tecnológica da madeira de Schizolobium amazonicum Huber ex Ducke de florestas plantadas no estado de Rondônia [tese]. Piracicaba: Escola Superior de Agricultura "Luiz de Queiroz"; 2016.

Mokfienski A, Colodette JL, Gomide JL, Carvalho AMML. A importância relativa da densidade da madeira e do teor de carboidratos no rendimento de polpa e na qualidade do produto. Ciência Florestal. 2008;18(3):407-19.

Morais PHD, Longue Júnior D, Colodette JL, Morais EHC, Jardim CM. Influence of clone harvesting age of Eucalyptus grandis and hybrids of Eucalyptus grandis x Eucalyptus urophylla in the wood chemical composition and in Kraft pulpability. Ciência Florestal. 2017;27(1):237-48.

Neves TA, Protássio TP, Trugilho PF, Valle MLA, Sousa LC, Vieira CMM. Qualidade da madeira de clones de Eucalyptus em diferentes idades para a produção de bioenergia. Revista de Ciências Agrárias. 2013;56(2):139-48.

Oliveira JTS, Souza LC, Della Lucia RM, Souza Júnior WP. Influência dos extrativos na resistência ao apodrecimento de seis espécies de madeira. Revista Árvore. 2005;29(5):819-26.

Quilhó T, Miranda I, Pereira H. Within-tree variation in wood fibre biometry and basic density of the urograndis Eucalypt hybrid (Eucalyptus grandis $\times$ E. urophylla). IAWA Journal. 2006;27(3):243-54.

Ribeiro VCN. Caracterização anatômica da matériaprima e avaliação das propriedades tecnológicas de painéis MDF de madeira de Schizolobium amazonicum Huber ex Ducke e de resíduos de espécies da Amazônia [dissertação]. Piracicaba: Escola Superior de Agricultura “Luiz de Queiroz”; 2015.

Rocha FT, Florsheim SMB, Couto HTZ. Variação das dimensões dos elementos anatômicos da madeira de árvores de Eucalyptus grandis Hill ex Maiden aos sete anos. Revista do Instituto Florestal. 2004;16(1):43-55.

Roque RM, Tomazello Filho M. Variação radial da estrutura anatômica do lenho de árvores de Gmelina arborea em diferentes condições de clima e de manejo na Costa Rica. Scientia Forestalis. 2009;37(83):273-85.

Sahrim H, Ibrahim FH, Shukor NAA. Anatomy of Acacia mangium grown in Malaysia. IAWA Journal. 1993;14(3):245-51.

Sannigrahi P, Ragauskas AJ, Tuskan GA. Poplar as a feedstock for biofuels: A review of compositional characteristics. Biofuels, Bioprod, Bioref. 2010;4(2):209-26.

Scandinavian Pulp, Paper and Board Testing Committee - SCAN. Testing committee. Stockholm: 1989. (SCAN 40:94).

Scott RW. Colorimetric determination of hexuronic acids in plant materials. Analytical Chemistry. 1979;51(7):936-41.

Sette Jr CR, Oliveira IR, Tomazello Filho M, Yamaji FM, Laclau JP. Efeito da idade e posição de amostragem na densidade e características anatômicas da madeira de Eucalyptus grandis. Revista Árvore. 2012;36(6):1183-90.

Silva DA, Trugilho PF. Comportamento dimensional da madeira de cerne e alburno 
utilizando-se metodologia de análises de imagem submetida a diferentes temperaturas. Cerne. 2003;9(1):56-65.

Silva JC, Tomazello Filho M, Oliveira JTS, Castro VR. Influência da idade e da posição radial nas dimensões das fibras e dos vasos da madeira de Eucalyptus grandis Hill ex. Maiden. Revista Árvore. 2007;31(6):1081-90.

Silva JJN, Cardoso GV, Silva Júnior FG, Stangerlin DM. Caracterização tecnológica da madeira de Schizolobium amazonicum para a produção de celulose Kraft. Ciência da Madeira. 2013;4(1):33-45.

Sjöström E. Wood chemistry: Fundamentals and applications. New York: Academic Press; 1981. p.169-89.

Soares VC, Bianchi ML, Trugilho PF, Höfler J, Pereira AJ. Análise das propriedades da madeira e do carvão vegetal de híbridos de eucalipto em três idades. Cerne. 2015;21(2):191-7.

Solar R, Kacik F, Melcer I. Simple semi-micro method for the determination of O-acetyl groups in wood and related materials. Nordic Pulp and Paper Research Journal. 1987;2(4):139-41.

Technical Association of the Pulp and Paper Industry - TAPPI. T $204 \mathrm{~cm}-97$ : Solvent extractives of wood and pulp. Atlanta: TAPPI Standard Method; 1998/1999.

Technical Association of the Pulp and Paper Industry - TAPPI. Standard T 211 om-12: Ash in wood, pulp, paper, and paperboard: Combustion at $525^{\circ} \mathrm{C}$. Atlanta: TAPPI Standard Method; 2012.

Technical Association of the Pulp and Paper Industry - TAPPI. Standard T 222 om-11: Acidinsoluble lignin in wood and pulp. Atlanta: TAPPI Standard Method; 2011.

Technical Association of the Pulp and Paper Industry - TAPPI T 207 om-93: Water solubility of wood and pulp. Atlanta: TAPPI Standard Method; 1994.

Technical Association of the Pulp and Paper Industry - TAPPI. T 249 cm-85 (R2009).

Carbohydrate composition of extractive-free wood and wood pulp by gas-liquid chromatography. Atlanta: TAPPI Standard Method; 2009.

Technical Association of the Pulp and Paper Industry - TAPPI. T $257 \mathrm{~cm}-85$ : sampling and preparing wood for analysis. Atlanta: TAPPI Standard Method, 1996.

Technical Association of the Pulp and Paper Industry - TAPPI. UM 250: Acid-soluble lignin in wood and pulp. Atlanta: TAPPI Standard Method, 1991.

Terezo RF, Szücs CA. Análise de desempenho de vigas em madeira laminada colada de paricá (Schizolobium Amazonicum Huber ex. Ducke). Scientia Forestalis. 2010;38(87):471-80.

Trugilho PF, Lima JT, Mendes LM. Influência da idade nas características físico-químicas e anatômicas da madeira de Eucalyptus saligna. Cerne. 1996;2(1):1-15.

Urbinati C, Azevedo AA, Silva EAM, Lisboa PLB. Wood structural quantitative variation of the Terminalia ivorensis A. Chev., Combretaceae. Acta Botânica Brasilica. 2003;17(3):421-37.

Valente BMDRT, Evangelista WV, Silva JDC, Lucia RMD. Variabilidade radial e longitudinal das propriedades físicas e anatômicas da madeira de angico-vermelho. Scientia Forestalis. 2013;41(100):485-96.

Wilkes J. Variations in wood anatomy within species of Eucalyptus. IAWA Bulletin N. S. 1988;9:13-23.

Willför S, Pranovich A, Tamminen T, Puls J, Laine C, Suurnäkki A, et al. Carbohydrate analysis of plant materials with uronic acid-containing polysaccharides - A comparison between different hydrolysis and subsequent chromatographic analytical techniques. Industrial Crops and Products. 2009;29(2-3):571-80.

Yeh T, Braun JL, Gldfarb B, Chang H, Kadla JF. Morphological and chemical variations between juvenile wood, mature wood and compression wood of loblolly pine (Pinus taeda L.). Holzforschung. 2006;60(1):1-8.

Zobel BJ, van Buijtenen JP. Wood variation: its causes and control. Berlin: Springer-Verlag; 1989.

Revista Árvore. 2018;42(3):e420301 